\title{
Preface: three key challenges to advancing entrepreneurship education and pedagogy
}

\section{Charles H. Matthews}

Welcome to Volume III of the Annals of Entrepreneurship Education and Pedagogy. The state of the art and science of entrepreneurship education is good. Yet, despite advances in content, delivery, evaluation, review, and feedback, there remains considerable work to be done. The following chapters contain a compendium of best practices, ideas, insights, and more from an incredibly diverse group of thought leaders from around the world.

The focus of this preface is a quite simple, yet compelling thesis about what is holding back the advancement of the field of Entrepreneurship, in general, and Entrepreneurship Education, in particular. It is posited here that two aspects of Entrepreneurship as a discipline must be addressed in order to advance Entrepreneurship Education beyond its current state. Those two aspects encompass continuing definitional and measurement issues. In addition, this paper explores options to overcome these issues.

1) One more time, what is entrepreneurship?

2) What is all the fuss over measuring entrepreneurship education success?

3) What is next (and next after next)?

a. Integrate research.

b. New tools, new rules: AI, IoT, Robotics.

c. Access to capital: ICO vs IPO.

d. Receptivity to disruptive innovation in education.

\section{ONE MORE TIME, WHAT IS ENTREPRENEURSHIP?}

Admit it, when you saw that sub-heading question, you had at least one (possibly more) of the following reactions. Check one or more of the following if your initial thought was 
a. "Here we go again, blah, blah, blah, blah. .."

b. Been there, done that.

c. It is whatever we want it to be.

d. It depends.

e. All the above.

f. None of the above.

Many of you have given up, toss up your hands, and go with the definition $d u$ jour. Entrepreneurship can only be situationally defined. Of course, therein lies the problem.

I know of no other academic (or non-academic for that matter) discipline that has allowed itself to be so abused and ultimately hijacked by others when it comes to what that discipline actually is. As a result, the word "entrepreneurship" continuously suffers a definitional crisis, which in turn, systematically obscures the core element of entrepreneurship education, and all that it encompasses.

For example, recently, a respected colleague who is an Associate Vice Chancellor in a large state university system gave a talk to a large forum of educators, researchers, practitioners, and policy makers. She began by saying, "Entrepreneurship is the management and innovation in our universities." Again, this is part of the problem. While a somewhat interesting thought (although I am not sure I understand what it means), this is NOT what Entrepreneurship is - not even close. Quite simply, entrepreneurship education cannot advance until we come to grips with this misuse of the word "entrepreneurship," and other related issues of how we define and use the lexicon of entrepreneurship, most notably the word "entrepreneurial."

The emerging academic discipline of entrepreneurship now finds itself with a terminological crisis brought on by the excessive use and overuse of the words "entrepreneur," "entrepreneurship," and especially the excessive overuse and misuse of the word "entrepreneurial." It is the misuse of the adjective "entrepreneurial" that has been the most damaging as it is now used synonymously with creativity and innovation and is often used gratuitously as a meaningless modifier (e.g., an entrepreneurial campus, entrepreneurial finance, entrepreneurial journey, or entrepreneurial spreadsheet).

Interestingly, the Management scholar Henry Mintzberg identified a similar terminological/definitional issue in the then emerging field of Strategy, noting that "If strategic planning is everything, then perhaps it is nothing" (Mintzberg, 1994). Perhaps an article will be written that parallels Mintzberg's critique of two decades ago, titled, "If entrepreneurship 
is everything, then perhaps it is nothing" (Solomon \& Matthews, 2014, p.91).

It is time to cement the core definition of Entrepreneurship and push back against the forces that overtly or inadvertently offer that Entrepreneurship is whatever we want it to be. It is time to cease the endless and unconscious use of the word "entrepreneurial" as a synonym for creative and/or innovative or as just a superfluous modifier.

At its core, entrepreneurship is the process of creating venture and value for multiple constituencies, including, but not limited to customers, employees, communities, and countries. Entrepreneurs are the individuals, acting alone or with others, who take and manage the risk and action to create the venture and value for those multiple constituencies. Are we up to the challenge?

\section{How Did this Definitional Crisis Come to Happen?}

In order to get a handle on addressing this problem, it is worth exploring the roots of the issue. Essentially, the problem has emerged from three interrelated aspects of Entrepreneurship as a discipline: 1) Entrepreneurship can came from anywhere; 2) The perpetuation that Entrepreneurship is first and foremost a "way of thinking"; and 3) the blatant abuse of the word "entrepreneurial."

\section{Entrepreneurship is indeed everywhere}

Individual entrepreneurs, corporate entrepreneurs or intrapreneurs, and social entrepreneurs seem to be everywhere and on everybody's mind. Moreover, Entrepreneurship encompasses multi-discipline specific and non-specific topics within its considerable reach. For example, Entrepreneurship can come from anyone, anywhere, at any time. It can emanate from the arts, sciences, technology, medicine, engineering, biology, chemistry, physics, new knowledge, and literally hundreds of other fields. As a "problem, solution, addressable market driven discipline," literally hundreds of other disciplines along the way inform Entrepreneurship and the entrepreneur's journey. For example, biomimicry offers incredible insight into the nexus of blending naturally occurring phenomena with the potential to engage in Entrepreneurship. At its core, Entrepreneurship is the process of the creation of venture and value that result from that nexus.

\section{A way of thinking}

The result of the complexities of these multiple interactions is an ever-expanding definition until it reaches its natural conclusion that 
Entrepreneurship is a "way of thinking" and thus whatever we deem it to be. Yes, it is a way of thinking, but then so are hundreds of other disciplines. Indeed, Entrepreneurship is an economic phenomenon, a scholarly domain, and a teaching subject (Shane \& Venkataram, 2000). Entrepreneurship is itself a multi-faceted, complex, social and economic phenomenon (Auderetsch, 2002); and yes, it is a way of thinking. At its core, however, it is about starting a new venture to create value.

\section{A matter of measurement}

The final aspect that has muddied the water so to speak is the ongoing assumption that the only true measure of entrepreneurship education is starting a venture. I am not sure how that become the single most critical metric, but once again, I do not know of another discipline that expects its students after only one (or even more) course(s) to immediately become that [here fill in the blank for any discipline]. Over my lifetime, I have taken multiple biology courses including a rather advanced collegiate genetics course. I am neither a biologist nor a geneticist. I took three accounting courses for my MBA, yet I am not an accountant. Moreover, there was not an expectation that I would be a biologist or an accountant. Yet, if someone takes just one entrepreneurship course, somehow the only measure of the efficacy of that class is to start a venture? Entrepreneurship students learn about the principles and practices and indeed may themselves become entrepreneurs, but that is not the only measure of meaning. Entrepreneurship students may indeed start a venture (small or accelerated scalable in nature) or may take their considerable learnings and apply it to working in a bank, a venture capital company, or consumer goods giant.

\section{What is Next?}

\section{How do we fix the problem?}

It is an interesting phenomenon that generally speaking many folks who are in the process of starting a venture are reluctant to call themselves an entrepreneur these days - that somehow that title should be reserved for only successful venturists. Curiously, it is as if that while in the process of starting a venture or as nascent entrepreneurs, they are just trying to start a business, not yet entrepreneurs. It becomes further complicated by the fact that a number of researchers only refer to the founders of "highly scalable" potential or ventures that have scaled as entrepreneurs, while the vast majority of start-ups which fall into the micro, small, and medium enterprise (MSME) categories are referred to as small business owners. That somehow MSME founders are not entrepreneurs. Of course, they are both entrepreneurs that are engaged alone or with others in the process 
of venture and value creation for multiple constituencies (see Solomon \& Matthews, 2014, p. 110).

To solve this dilemma, as a discipline we need to engage on several fronts. At a somewhat simple, yet extremely challenging level, we need to stop allowing our discipline specific words "entrepreneurship," "entrepreneur" and "entrepreneurial" to be hijacked by everyone and anyone. As it turns out, "entrepreneurial" is too far-gone now and will need to be banned until treatment and recovery can ensue. In the meantime, not everyone is an entrepreneur and all business and social activity is not entrepreneurship. Entrepreneurship is the creation of venture and value for multiple constituencies and as such becomes the engine of economic development. Creativity and innovation are its fuel. Creativity and innovation are not synonyms for entrepreneurship or entrepreneurial.

\section{It is time to temporarily ban the word "entrepreneurial"}

It may seem a bit drastic, but if there one word that is the most problematic when it comes to solving the problem, it is the overuse and abuse of the word "entrepreneurial." Everyone is not an entrepreneur and everything is not entrepreneurial, but the juggernaut of what I call "business comfort food words" appears to be unstoppable - and "entrepreneurial" is at the top of the list. It is just so easy and comfortable to throw in the blasé "entrepreneurial" in front of everything and I mean everything - from entrepreneurial spreadsheets, to entrepreneurial finance, to entrepreneurial campus. There is nothing entrepreneurial about the damn spreadsheets, financing, or campus! "Oh, he is just being entrepreneurial" when they really mean anything from criminal to crazy to creative and everything in between. Coming clean, I am as guilty as the next entrepreneurship scholar, having overused the word entrepreneurial myself in my early writing, but it has to stop. It is not going to be easy.

Dean Shepherd, immediate past editor of Journal of Business Venturing, and I go back quite a way and I consider him one of the top thought leaders in the field of Entrepreneurship. On the occasion of the 30th anniversary of the $J B V$, he penned a simply brilliant 18-page editorial in the journal (Shepherd, 2015). I have used it many times when leading doctoral student seminars in our university program, as well as for International Council for Small Business (ICSB) and others. Yet, when I called/emailed him to compliment his writing, but mentioned his incredible overuse of the word "entrepreneurial" in the editorial (excluding references, over 150 times), he readily acknowledged it was a problem, but said he was powerless to stop using it. I said as the editor of arguably the leading academic Entrepreneurship journal and a thought leader in the field, if he felt powerless to do something about it, as a discipline we were 
doomed. Interestingly, in 2014, the Academy of Management Annual Conference Theme was "The Power of Words." Curious, I began to count the number of times the word entrepreneurial appeared in the program. I stopped counting at 200, although my favorite example was from a paper abstract that noted, ". . . entrepreneurship provides a context for general psychological theory rather than an arena for developing unique [wait for it] entrepreneurial psychological theory [emphasis added]" (Academy of Management Program, 2014). I rest my case.

Consequently, the word "entrepreneurial" has become virtually meaningless because of its overuse and abuse (e.g., if one more university lists one of its goals to be a more "entrepreneurial campus" I will absolutely scream - there nothing entrepreneurial about the damn campus).

Entrepreneurship is the art and science of taking and managing the risk and action to create a venture and value for multiple constituents. The entrepreneur who engages in the process of entrepreneurship can be founders of small business ventures either (steady or small business growth ventures or SBGVs) or potentially accelerated scalable growth ventures (accelerated scalable growth ventures or ASGVs). As Solomon \& Matthews (2014) note, while these two entrepreneurship paths (SBGV versus ASGV) are divergent in nature they can be convergent (SBGVs morph into ASVGs and vice-versa), and they have different pedagogical and curricular needs (p. 110). (In this volume, please see Chapter 3, Nawaf Alabduljader, Ravi S. Ramani, and George Solomon, "Entrepreneurship education: a qualitative review of US curricula for steady and high growth potential ventures").

In addition, as a discipline, we need to integrate our research more closely with entrepreneurship education. That is, we need to engage more in the scholarship of entrepreneurship education. We are entering a new era governed by new tools and new rules. Artificial Intelligence (AI), the Internet of Things (IoT), and Robotics are changing how we teach and learn. Initial Coin Offerings (ICOs) are just part of new financing and exiting options, along with regulated crowd source funding platforms. Are we ready for these changes as a discipline? Unless we address our definitional, measurement, and terminology use issues, we may find ourselves falling further behind than leading the next generation of start-ups. Are you up for the challenge?

\section{In this Volume}

The authors of the chapters in this volume are definitely up to the challenge of advancing entrepreneurship education on multiple fronts. From the Internet of Things (IoT) to the impact on education to the role of business plans as a pedagogical tool to the role of entrepreneurship student's 
entrepreneurship self-efficacy and co-curricular considerations to the political use of entrepreneurship as an economic panacea, and much more.

For example, if you are even just a little aware of the technology revolution in entrepreneurship and entrepreneurship education, you will want to read Chapter 9, Raj V. Mahto, William McDowell, Sandipen Sen, and Saurabh Ahluwalia, "Internet of Things (IoT) and entrepreneurship education: opportunities and challenges." This chapter delves into the intersection of entrepreneurship education and technology. The authors provide an interesting perspective on the state of the art of entrepreneurship education and the current and future potential of the Internet of Things (IoT) to transform the who, what, where, when and how of entrepreneurship education. By providing key examples, the authors provide the reader a compelling picture of the concept of IoT and its current and potential application in entrepreneurship education and training. A discussion of the status of IoT developments in the education sector and implications for entrepreneurship faculty and colleges is provided along with key challenges faced by higher education in optimizing the use of IoT in general and entrepreneurship education in particular.

In Chapter 4, contributor Dr. Ying Zhang takes on the future of education in general, business education in particular, and entrepreneurship education at a more granular level hold or promises to hold the keys to advancing society on multiple fronts including, but not limited to economically, socially, sustainability, equitably, and more. (Ying Zhang, "Business and educational entrepreneurship: purpose and future"). Unquestionably, this has profound ramifications for not only education in and of itself, but business education and entrepreneurship as a discipline, an economic phenomenon, a way of life, and more. The author provides a deep look into intersection of education and society, business and economic advancement, and creating a life worth living. Dr. Zhang builds on a career spanning the scope of education from elementary to secondary to higher education and shares keen insights on where we are, where we are going, and how we plan to get there. She proposes a Hybrid Enterprise Model of Business Education which 1) Acknowledges and respects that system's internal and external factors, determining its management principles; 2) Argues that if a proposed ideal business education is to carry out a collective vision of social value and to improve the well-being of stakeholders, it must take a network approach to its inputs, processes, and outputs; and 3) Should provide students not only with scientific intellectual property - by transferring outside knowledge, but with what might be called inner knowledge. Powerful reading!

Author Dr. Jerry Katz sets a provocative entrepreneurship education tone in the title of Chapter 7, "The business plan: reports of its death have 
been greatly exaggerated." Are business plans really useless or have we failed to fully consider the potential of this pedagogical tool? Perhaps it is time to rethink the role and use of business plans in our entrepreneurship pedagogy.

Authors Prateek Shekhar, Aileen Huang-Saad, and Julie Libarkin, (see Chapter 12, "Examining differences in students' entrepreneurship self-efficacy in curricular and co-curricular entrepreneurship education programs") make a significant contribution to the field of entrepreneurship education and this volume across three fronts. 1) It articulates a perspective on curricular and co-curricular entrepreneurship education that has not been examined to date. 2) Moreover, it compares the value of curricular and co-curricular entrepreneurship education beyond the unidimensional thinking that entrepreneurship education can only result in student start-ups. 3) By expanding the entrepreneurship education perspective and testing a comparative sample, the authors provide a number of key considerations why both curricular and co-curricular approaches to entrepreneurship education are valuable.

Dr. Benson Honig posits in Chapter 11 ("Entrepreneurship as a political tool: the implications of compensatory entrepreneurship") that perhaps we have gone too far with our expectations of Entrepreneurship and by extension, entrepreneurship education, the great political cure of all economic woes. This is a must-read chapter.

Whenever I teach my undergraduate or graduate class in Entrepreneurship, I always end it with the same lines: "My greatest hope is that each of you will enjoy the success of your life and career pursuits, that for many of you will include creating venture and value. Now go forth and use your new-found powers for good and not evil." The pursuit of life inevitably encounters both, but my admonition is that we should be agents for good. Yet, that does not always happen. In this chapter, Professor Honig lays out a compelling case for what he terms "Compensatory Entrepreneurship". It is defined as the political endorsement of entrepreneurship promotion activities, including training, incubation, and media dissemination, for the primary objective of maintaining political and/or economic control of one population over another. Unquestionably, this has profound ramifications for Entrepreneurship as a discipline, a teaching/learning subject, an economic phenomenon, and more. The author provides a deep look into the political/legal aspects of entrepreneurship as more than the sum of its parts and examines the consequences for both our work as entrepreneurship scholars/educators and the pursuits of our students.

Of course, this is just a sampling of the many thought-provoking insights offered in this volume for your consideration, debate, use, and 
more. Read it from cover to cover or pick and choose a chapter here or there. Either way, you will not be disappointed. Enjoy!

\section{REFERENCES}

Academy of Management Annual Meeting Program (2014). "The Power of Words." Philadelphia, PA: Academy of Management.

Audretsch, D. (2002). "The Dynamic Role of Small Firms: Evidence from the U.S.” Small Business Economics, 18: 13-40.

Mintzberg, H. (1994). "The Fall and Rise of Strategic Planning." Harvard Business Review, 107-114.

Shane, S. \& Venkataram, S. (2000). The Promise of Entrepreneurship as a Field of Research," Academy of Management Review, 25(1), 217-226.

Shepherd, D. (2015). "Party On! A call for entrepreneurship research that is more interactive, activity based, cognitively hot, compassionate, and prosocial.” 30(4) July: 489-507.

Solomon, G. and Matthews, C. (2014). "The curricular confusion between entrepreneurship education and small business management: A qualitative analysis" in Michael Morris and \& Eric W. Liguori (Eds.), Annals of Entrepreneurship Education \& Pedagogy. Cheltenham: Edward Elgar. 